\title{
Intestinal Absorption of Cholesterol by Patients with Smith-Lemli-Opitz Syndrome
}

\author{
DON S. LIN, ROBERT D. STEINER, DONNA P. FLAVELL, AND WILLIAM E. CONNOR \\ Division of Endocrinology, Diabetes and Clinical Nutrition, Department of Medicine [D.S.L., D.P.F., \\ W.E.C.], Oregon Health \& Science University, Portland, Oregon 97239; and Departments of Pediatrics \\ and Molecular and Medical Genetics [R.D.S.], Child Development and Rehabilitation Center, \\ Doernbecher Children's Hospital Portland, Oregon 97239
}

\begin{tabular}{|c|c|}
\hline \multicolumn{2}{|c|}{ ABSTRACT } \\
\hline $\begin{array}{l}\text { The Smith-Lemli-Opitz syndrome (SLOS) is a disorder of } \\
\text { impaired cholesterol biosynthesis because of a deficiency of the } \\
\text { enzyme } 7 \text {-dehydrocholesterol- } \Delta^{7} \text {-reductase, in the last step in } \\
\text { cholesterol biosynthesis. Dietary cholesterol has been proposed } \\
\text { as a potential therapy for SLOS and is being tested currently. } \\
\text { Because there is no information on cholesterol absorption in } \\
\text { SLOS, we recruited } 12 \text { SLOS patients into the General Clinical } \\
\text { Research Center for } 1 \text {-wk periods for administration of test meals } \\
\text { and for blood and stool collections. A test breakfast that con- } \\
\text { tained tracer cholesterol- } 4-C^{14} \text { with egg yolk or with crystalline } \\
\text { cholesterol in suspension was given subsequently. Twenty-four } \\
\text { and } 48 \text {-h blood and } 1 \text {-wk stool samples then were collected. The } \\
\text { radioactivities in these samples were analyzed to determine the } \\
\text { absorption of cholesterol by these patients. In } 11 \text { patients who } \\
\text { were given egg yolk cholesterol, cholesterol absorption was } 27.3 \\
\pm 6.7 \% \text {. The absorption was slightly less at } 20.5 \pm 10.3 \% \text { but } \\
\text { not significantly different for the six patients who were given }\end{array}$ & $\begin{array}{l}\text { crystalline cholesterol. There was a positive correlation between } \\
\text { the absorption of isotopic cholesterol as measured by determi- } \\
\text { nation of radioactive cholesterol in stool and the amount of } \\
\text { isotopic cholesterol in the plasma at } 24 \text { and } 48 \mathrm{~h} \text { after the meal. } \\
\text { Our data indicated that SLOS patients absorb cholesterol from } \\
\text { the diet. However, the percentage of absorption is lower than } \\
\text { reported values for normal adults and for hypercholesterolemic } \\
\text { children. The absorption of crystalline cholesterol in suspension } \\
\text { was slightly lower than the absorption of cholesterol in egg yolk } \\
\text { cholesterol by these patients. The absorption of cholesterol may } \\
\text { ameliorate some of the biochemical and developmental deficits } \\
\text { in SLOS patients. (Pediatr Res 57: 765-770, 2005) } \\
\text { Abbreviations } \\
\text { GCRC, General Clinical Research Center } \\
\text { SLOS, Smith-Lemli-Opitz syndrome } \\
\text { 7-DHC, 7-dehydrocholesterol }\end{array}$ \\
\hline
\end{tabular}

The Smith-Lemli-Opitz Syndrome (SLOS) (1) is an autosomal recessive disorder that is characterized by microcephaly, cleft palate, mental retardation, growth retardation, dysmorphic facies, limb abnormalities (especially syndactyly of the toes), genital disorders, endocrine malfunction, cataracts, and heart and kidney malformations (1-8). This disease is estimated to occur in 1 in 20,000 births, making it one of the most common autosomal recessive disorders $(4,8)$. The carrier frequency is 1 in 30 (9).

Received July 26, 2004; accepted October 13, 2004.

Correspondence: William E. Connor, M.D., Department of Medicine, L465, Oregon Health \& Science University, 3181 SW Sam Jackson Park Road, Portland, OR 972393098; e-mail: connorw@ohsu.edu.

This project was supported by grants from the National Heart, Lung, and Blood Institute (HL64618 and HL 073981) and by a grant from the American Academy of Pediatrics Section on Genetics and Birth Defects and by a General Clinical Research Center grant (PHS M01RR000334). R.D.S. is a Clinical Associate Physician of the General Clinical Research Centers (PHS M01-RR000334-33S3). We also acknowledge support from the Collins Foundation and the Smith-Lemli-Opitz Advocacy and Exchange and the Oregon Child Health Research Center (National Institute of Child Health and Human Development, PHS P30-HD33703-04).

DOI: 10.1203/01.PDR.0000157723.98422.B5
Finding reduced cholesterol and elevated 7-dehydrocholesterol (7-DHC) levels in the plasma and tissues of these patients, Tint and colleagues (10-13) postulated that SLOS resulted from a defect in cholesterol and bile acid biosynthesis. In hepatocytes and fibroblasts from affected individuals, the enzyme 7-DHC $\Delta^{7}$-reductase (EC 1.3.1.21) that converts 7-DHC to cholesterol in the final step of cholesterol biosynthesis was found deficient $(14,15)$. Porter and colleagues together with our group and others (16-18) found mutations in the 7-DHC $\Delta^{7}$-reductase gene, which causes SLOS.

The clinical manifestations of SLOS may result from cholesterol deficiency or from the potential toxicity of precursor sterols, particularly 7-DHC (normally absent or detected in only trace quantities in plasma) or a combination of both. Cells use cholesterol for membrane synthesis and as a precursor for steroid hormones and bile acids.

Cholesterol is also needed for autoprocessing (activation) of Sonic hedgehog, an important protein in the early limb patterning and craniofacial development in the human embryo 
(19-21). Abnormal Sonic hedgehog activation and/or signaling may explain the malformations in SLOS (22). The potential toxicity of 7-DHC has been shown in a rat model and in tissue culture studies $(23,24)$.

In our recent sterol balance study, we found that whole-body cholesterol synthesis is reduced in patients with SLOS and that the synthesis of 7-DHC and other cholesterol intermediates is profoundly increased (25). This evidence strengthened the rationale for the use of dietary cholesterol in treatment protocols. Feeding egg yolk cholesterol to these SLOS patients, we found that there was an increase in plasma cholesterol and a decrease in plasma 7-DHC (26). The increase of plasma cholesterol after dietary cholesterol feeding suggested considerable intestinal absorption of cholesterol by these patients. However, the efficiency of cholesterol absorption in these patients is not known. Abnormal bile acids in SLOS patients have been reported $(6,27)$. In our sterol balance study, although it was not statistically significant, somewhat lower bile acid excretion in these patients was observed (25). Because bile acids are an important component of micellar complex for cholesterol absorption, any defect in bile acid production might have a significant effect on cholesterol. Therefore, deficiency in cholesterol absorption may exist in these patients. Furthermore, the effects of factors such as the form of cholesterol in the test meal or the severity of SLOS and others on cholesterol absorption in SLOS patients are not known. An early study showed that in normal individuals, crystalline cholesterol was poorly absorbed compared with egg yolk cholesterol (28). Wang and Carey (29) reported that the cholesterol delivery vehicle has a significant effect on cholesterol absorption. A total of eight different oils and skim milk were tested as cholesterol delivery vehicles in an absorption test. Cholesterol absorption was lowest in mice that were fed corn oil in the test meal $(28 \pm 6 \%)$ and highest in animals that were fed safflower oil $(57 \pm 6 \%)$ or skim milk $(65 \pm 6 \%)$.

In the present study, we measured the cholesterol absorption in 12 SLOS patients after a single test meal that contained isotopic cholesterol. Because both egg yolk and crystalline cholesterol have been used in treatment protocols involving SLOS patients $(26,30)$, the possible effect of the form of cholesterol (egg yolk versus crystalline) in the test meal was also examined.

\section{METHODS}

With the approval of our institutional review board, 12 SLOS patients were admitted to the General Clinical Research Center (GCRC) for 1-wk periods. Their diets were monitored carefully by the GCRC dietitians as described previously to allow precise dietary cholesterol content determination (25). For a cholesterol absorption test, each patient was given an isotopic test meal in the morning as previously described (31). The test meal was composed of cholesterol-4- ${ }^{14} \mathrm{C}$, sitostanol-5,6- ${ }^{3} \mathrm{H}$ sitostanol, and trace amounts of cholesterol in canola oil mixed with egg yolk cholesterol or crystalline cholesterol. The composition of the meal was adjusted according to age and weight of the patient. The dose of cholesterol was $16 \pm 10 \mathrm{mg} / \mathrm{kg}$. The dose of isotopes was calculated by our Human Isotope Use Committee according to the age of these children. Blood samples were obtained 24 and $48 \mathrm{~h}$ after the meal. Complete stools for the 1-wk period were collected. Five SLOS patients were tube-fed because of sucking and swallowing difficulties, but the same procedures were applied to the diet of those individuals.

Cholesterol absorption was evaluated by two methods: 1) measurement of radioactivity in the plasma and 2) the radioactivity in the feces after the single breakfast meal that contained isotopic cholesterol and two different forms of cholesterol (egg yolk or crystalline cholesterol in suspension) (31). For determining the radioactivity in the plasma, plasma samples were collected 24 and $48 \mathrm{~h}$ after the meal. The plasma was saponified with alcoholic $\mathrm{KOH}$. Plasma sterols were extracted with hexane and analyzed with the same methods as described in our previous publications $(25,32)$. Plasma sterols formed trimethylsilyl ether derivatives and were subjected to gas liquid chromatography (GLC) analysis. The samples were analyzed by a GLC that was equipped with a hydrogen flame ionization detector (Perkin-Elmer Autosystem XL gas chromatography) and contained $25 \mathrm{~m}$ cp-wax-57 capillary column (Chromapack-Varian, Walnut Creek, CA) with $0.32 \mathrm{~mm}$ i.d. and $0.25-\mu \mathrm{m}$ film thickness. The column temperature was $205^{\circ} \mathrm{C}$. Helium was used as carrier gas and cholestane as an internal standard. An aliquot of plasma was taken for radioactivity analysis.

After saponification, hexane extract of plasma sterols was transferred into counting vials. Radioactivities in the samples were measured by a Beckman model LS-6500 scintillation counter. Radioactivity in plasma was expressed as cholesterol specific activities (dpm/mg cholesterol).

Cholesterol absorption based on radioactivity in the stool was determined according to the method described previously $(31,33)$. During the experimental period, all patients stayed $1 \mathrm{wk}$ in the GCRC for isotope administration and sample collections. Each child was given a test meal that contained $300 \mathrm{mg}$ of cholesterol as egg yolk or a crystalline cholesterol suspension (Oraplus; Paddock Laboratory Inc., Minneapolis, MN). The dose of cholesterol and radioisotopes was adjusted according to the age and weight of the patients. Cholesterol-4- $\mathrm{C}^{14}$ and sitostanol-5,6- ${ }^{3} \mathrm{H}$ were dissolved in canola oil. As sitostanol was nonabsorbable, it was used as a marker for stool recovery. The meal was prepared as "scrambled eggs" and served in conjunction with the usual breakfast. For tube-fed infants, the egg yolk-oil mixture was mixed with formula before administration. For calculation of the precise intake of radioactive cholesterol, the radioactivity left in the eating utensils (including uneaten portion of the meal, if any) of each patient was measured and subtracted from the total radioactivity administered. Stools were collected for the next $7 \mathrm{~d}$ after the test meal and analyzed for radioactivity. Our procedure is the same technique named "fecal dual-isotope method" in a recent article by Wang and Carey (29). The formula for calculations is

$$
\% \text { Chol. Absorption }=\frac{\mathrm{C}^{14} / \mathrm{H}^{3} \text { dose mixture }-\mathrm{C}^{14} / \mathrm{H}^{3} \text { feces }}{\mathrm{C}^{14} / \mathrm{H}^{3} \text { dose mixture }} \times 100
$$

Because most of the SLOS patients were infants, we have developed a system for performing sterol balance in infants and children without having to use a metabolic frame. We have been able to scrape stool from frozen cloth diapers and measure sterols and bile acids in pooled stool samples (25). Toilet-trained patients collected all stools; the stools were placed individually in labeled plastic bags and frozen for later analysis.

Seven-day stools of these patients were pooled and homogenized with equal amounts of water. An aliquot was taken and frozen immediately. For analysis of the radioactivities in the stool, a previously published method for fecal neutral sterolanalysis was used(33,34). A total of 0.5 -to 1.0 -galiquots were weighed out and saponified in alcoholic $\mathrm{NaOH}$. Fecal neutral sterols were extracted with hexane. The sample was purified further by thin layer chromatography (TLC) and extracted from TLC powder with ether. Radioactivities in the neutral sterol fraction then were measured by a Beckman model LS-6500 scintillation counter.

\section{RESULTS}

Twelve SLOS patients were included in the current study. The clinical data of these patients are depicted in Table 1. There were five male and seven female patients. Their ages ranged from 6 mo to $23.5 \mathrm{y}$. Their blood cholesterol levels on their first visit to the clinic were $39.2-181 \mathrm{mg} / \mathrm{dL}$. Levels of 7-DHC ranged from 0.3 to $13.2 \mathrm{mg} / \mathrm{dL}$.

Cholesterol absorption data for 11 patients who were fed egg yolk cholesterol in the test meal are presented in Table 2. The cholesterol content in the test meal ranged from 78 to $473 \mathrm{mg}$. Isotopic cholesterol intake was 0.793-4.966 $\mu \mathrm{Ci}$. The mean plasma cholesterol specific activity (dpm/mg cholesterol) was $289 \pm 199$ and $325 \pm 203$ for blood collected 24 and $48 \mathrm{~h}$ after the test meal, respectively. ${ }^{3} \mathrm{H}$ was not found in the plasma. 
Table 1. Clinical data of experimental subjects

\begin{tabular}{|c|c|c|c|c|c|c|c|c|}
\hline \multirow[b]{2}{*}{$\begin{array}{c}\text { Subject } \\
\text { number* }\end{array}$} & \multirow[b]{2}{*}{ Age (y) } & \multirow[b]{2}{*}{ Sex } & \multirow[b]{2}{*}{$\begin{array}{l}\text { Height } \\
(\mathrm{cm})\end{array}$} & \multirow[b]{2}{*}{$\begin{array}{l}\text { Weight } \\
(\mathrm{kg})\end{array}$} & \multicolumn{3}{|c|}{ Plasma sterols (mg/dL) } & \multirow[b]{2}{*}{ Tube-fed } \\
\hline & & & & & Cholesterol & 7-DHC & $\begin{array}{c}\text { 7-DHC/ } \\
\text { Cholesterol }\end{array}$ & \\
\hline $1 b$ & 3.5 & & 94.5 & 12.6 & 119.5 & 2.4 & 0.020 & \\
\hline $2 \mathrm{a}$ & 3.3 & M & 103.0 & 14.3 & 168.6 & 1.3 & 0.008 & No \\
\hline $2 b$ & 4.5 & & 112.3 & 16.1 & 181.3 & 1.7 & 0.009 & \\
\hline $3 a$ & 8.7 & $\mathrm{~F}$ & 107.0 & 16.3 & 39.2 & 12.4 & 0.316 & Yes \\
\hline $4 a$ & 2.9 & M & 80.0 & 9.4 & 94.8 & 4.8 & 0.051 & No \\
\hline $4 \mathrm{~b}$ & 3.5 & & 82.2 & 10.8 & 136.0 & 4.1 & 0.030 & \\
\hline $5 \mathrm{a}$ & 8.6 & $\mathrm{~F}$ & 114.0 & 17.8 & 125.2 & 2.3 & 0.018 & No \\
\hline $5 b$ & 7.6 & & 110.6 & 17.4 & 127.4 & 1.7 & 0.013 & \\
\hline $6 a$ & 3.1 & $\mathrm{~F}$ & 88.5 & 11.3 & 121.1 & 0.6 & 0.005 & No \\
\hline $6 b$ & 2.7 & & 86.0 & 10.4 & 141.2 & 0.3 & 0.002 & \\
\hline $12 b$ & 0.6 & F & 62.9 & 5.1 & 76.8 & 7.6 & 0.099 & Yes \\
\hline
\end{tabular}

* a, test meal: egg yolk cholesterol; b, test meal: crystalline cholesterol.

Table 2. Intestinal absorption of cholesterol in SLOS patients who were fed the test breakfast of egg yolk

\begin{tabular}{|c|c|c|c|c|c|}
\hline \multirow[b]{2}{*}{ Patients } & \multicolumn{2}{|c|}{ Cholesterol in test meal } & \multicolumn{2}{|c|}{$\begin{array}{c}\text { Plasma cholesterol specific } \\
\text { radioactivities } \\
(\mathrm{dpm} / \mathrm{mg} \text { cholesterol })\end{array}$} & \multirow{2}{*}{$\begin{array}{l}\text { Cholesterol absorption } \\
\text { ( } \% \text { of amount given) }\end{array}$} \\
\hline & Mass (mg) & Radioactivities $(\mu \mathrm{Ci})$ & $24 \mathrm{~h}$ & $48 \mathrm{~h}$ & \\
\hline $1 \mathrm{a}$ & 183 & 1.786 & 50 & 79 & 21.6 \\
\hline $2 \mathrm{a}$ & 184 & 2.470 & 267 & 263 & 32.4 \\
\hline $3 a$ & 252 & 3.510 & 744 & 744 & 22.5 \\
\hline $4 \mathrm{a}$ & 148 & 1.193 & 203 & 287 & 24.1 \\
\hline $6 a$ & 124 & 0.995 & 150 & 152 & 18.2 \\
\hline $7 \mathrm{a}$ & 378 & 3.617 & 441 & 494 & 33.6 \\
\hline $8 a$ & 378 & 3.665 & 245 & 356 & 21.9 \\
\hline $9 \mathrm{a}$ & 473 & 3.751 & 193 & 214 & 31.7 \\
\hline $10 \mathrm{a}$ & 78 & 0.793 & 90 & 90 & 36.4 \\
\hline $11 \mathrm{a}$ & 298 & 4.966 & 342 & 535 & 22.3 \\
\hline Mean \pm SD & $248 \pm 122$ & $2.743 \pm 1.374$ & $289 \pm 199$ & $325 \pm 203$ & $27.3 \pm 6.7$ \\
\hline
\end{tabular}

The cholesterol absorption (percentage of amount of cholesterol given that was absorbed) was $27.3 \pm 6.7 \%$ in the 11 patients who were fed an egg yolk cholesterol meal.

The data of cholesterol absorption of patients who were fed crystalline cholesterol in suspension in the test meal are shown in Table 3. Seven patients were included in this experiment. The isotopic cholesterol in the test meal was $0.951-3.739 \mu \mathrm{Ci}$. The cholesterol specific radioactivities were $220 \pm 168$ in 24-h blood and $244 \pm 175$ in 48-h blood. Cholesterol absorption was $20.5 \pm 10.3 \%$.

Table 3. Intestinal absorption of crystalline cholesterol of SLOS patients who were fed the test breakfast

\begin{tabular}{|c|c|c|c|c|c|}
\hline \multirow[b]{2}{*}{ Patients } & \multicolumn{2}{|c|}{ Cholesterol in test meal } & \multicolumn{2}{|c|}{$\begin{array}{c}\text { Plasma cholesterol specific } \\
\text { radioactivities } \\
\text { (dpm/mg cholesterol) }\end{array}$} & \multirow[b]{2}{*}{$\begin{array}{l}\text { Cholesterol absorption } \\
\text { ( } \% \text { of amount given) }\end{array}$} \\
\hline & Mass (mg) & $\begin{array}{l}\text { Radioactivities } \\
\qquad(\mu \mathrm{Ci})\end{array}$ & $24 \mathrm{~h}$ & $48 \mathrm{~h}$ & \\
\hline $1 b$ & 204 & 1.658 & 44 & 36 & 12.7 \\
\hline $2 b$ & 181 & 3.236 & 325 & 345 & 21.0 \\
\hline $3 b$ & 782 & 3.739 & 391 & 403 & 15.8 \\
\hline $5 b$ & 249 & 3.593 & 453 & 490 & 39.6 \\
\hline $6 \mathrm{~b}$ & 400 & 1.226 & 64 & 53 & 13.7 \\
\hline $12 b$ & 110 & 0.951 & 90 & 159 & 11.6 \\
\hline Mean \pm SD & $298 \pm 233$ & $2.217 \pm 1.249$ & $220 \pm 168$ & $244 \pm 175$ & $20.5 \pm 10.3$ \\
\hline
\end{tabular}


Eleven patients had a test meal that contained egg yolk cholesterol, and seven patients had a test meal that contained crystalline cholesterol. The egg yolk group had higher mean cholesterol absorption than the crystalline group. However, the difference was not statistically different $(27.3 \pm 6.7$ versus 20.5 \pm 10.3; $p<0.107$; Table 4). Six patients had cholesterol absorption measured two times, once with egg yolk cholesterol and once with crystalline cholesterol in suspension. The time between the two diets ranged from 5 mo to $1 \mathrm{y}, 3$ mo (children 1-6). Four patients had egg yolk meal test first; two had crystalline meal test first. The order of the test diets was random. There was always a washout period of at least 3 mo between test diets. Paired tests of the results of 6 patients who had both egg yolk and crystalline cholesterol test meals showed no statistical difference in the percentage absorbed by the two diets ( $25.8 \pm 6.9$ versus $21.9 \pm 10.5 ; p<0.215$; Table 4$)$.

To test the relationship between the levels of plasma radioactivity versus absorption as calculated from measurement of stool radioactivity, we carried out a linear regression test between the plasma cholesterol specific radioactivities in the 24- and 48-h blood samples after the test meal and the absorption of cholesterol on the basis of the stool analysis. The two parameters were highly correlated. For the 24-h blood specimen, the correlation coefficient labeled as $r$ or $r^{2}$ as appropriate was 0.594 ( $p<0.009$; Fig. 1). For the 48 -h blood, the correlation coefficient was $0.474(p<0.047$; Table 5). There were no correlations between the percentage of cholesterol absorbed and age, cholesterol level, 7-DHC level, and the ratio of 7 DHC to cholesterol and to total sterols.

Among our 12 patients tested, five of them were tube-fed (representing the more severely ill) and seven were fed the usual breakfast. The cholesterol absorption of five tube-fed patients was $20.7 \pm 8.1 \%$, and the absorption of the other seven patients was $28.2 \pm 7.7 \%$. The tube-fed patients seemed to have slightly lower absorption. However, the difference was not statistically significant $(p<0.136)$, perhaps because of smaller numbers.

\section{DISCUSSION}

Because of the defect in cholesterol biosynthesis, SLOS patients have low plasma cholesterol and high 7-DHC and 8-DHC levels. These abnormalities are likely responsible for their clinical manifestations as outlined before. Previously, we had found that feeding egg yolk to these patients after a cholesterol-free diet increased the plasma cholesterol level and decreased 7-DHC (26). Much of the increased plasma cholesterol was as LDL. These data suggested indirectly that these patients were able to absorb dietary cholesterol. However, there was no direct information about how well dietary cho-

Table 4. Cholesterol absorption of subjects who were fed different forms of cholesterol (egg yolk vs crystalline) in test meal

\begin{tabular}{llcll}
\hline Comparison & Form & No. of subjects & Absorption & $p$ value \\
\hline \multirow{2}{*}{ Group $t$ test } & Egg yolk & 11 & $27.3 \pm 6.7$ & $<0.107$ \\
& Crystalline & 7 & $20.5 \pm 10.3$ & \\
Paired $t$ test & Egg yolk & 6 & $25.8 \pm 6.9$ & $<0.215$ \\
& Crystalline & 6 & $21.9 \pm 10.5$ & \\
\hline
\end{tabular}

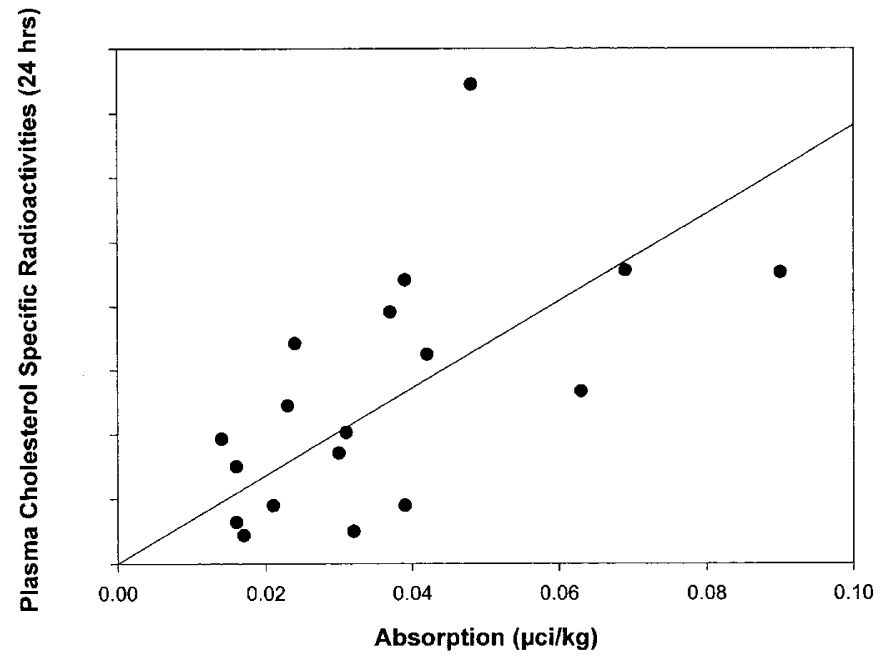

Figure 1. Correlation between measured isotopic cholesterol absorption $(\mu \mathrm{Ci} / \mathrm{kg})$ and plasma cholesterol specific radioactivities $(\mathrm{dpm} / \mathrm{mg})$ in plasma $24 \mathrm{~h}$ after the isotopic meal.

Table 5. Correlation between measured isotopic cholesterol absorption $(\mu \mathrm{Ci} / \mathrm{kg})$ and cholesterol specific radioactivity $(\mathrm{dpm} / \mathrm{mg}$ cholesterol) in the plasma 24 and $48 \mathrm{~h}$ after the isotopic meal

\begin{tabular}{ccccc}
\hline $\begin{array}{c}\text { No. of } \\
\text { subjects }\end{array}$ & $\begin{array}{c}\text { No. of } \\
\text { tests }\end{array}$ & $\begin{array}{c}\text { Time of blood } \\
\text { collection }\end{array}$ & $\begin{array}{c}\text { Correlation } \\
\text { coefficient }(\mathrm{Y})\end{array}$ & $p$ value \\
\hline 12 & 18 & $24 \mathrm{~h}$ & 0.594 & $<0.009$ \\
12 & 18 & $48 \mathrm{~h}$ & 0.474 & $<0.047$ \\
\hline
\end{tabular}

lesterol was absorbed by these patients and whether the absorption can be affected by various factors. In this study, we found the efficiency of absorption of cholesterol by SLOS patients to be $27.3 \pm 6.7 \%$ of the amount given. Unfortunately, there were no data in the literature about cholesterol absorption in normal children for comparison. Using the same technique, we had previously measured the cholesterol absorption in normal adults and type II hypercholesterolemic adults. These were similar: $43.7 \pm 8.4$ and $42.3 \pm 13.4 \%$, respectively (31). Trying to make a comparison between normal individuals and SLOS patients, in the normal adult group, we picked the three youngest with ages 33-36 y; their cholesterol absorption was $39.0 \pm 7.6 \%$. In comparison, our only adult SLOS patient was $24 \mathrm{y}$ old. Her cholesterol absorption was $22.3 \%$. Therefore, for comparable ages, the cholesterol absorption of the SLOS patients seems lower than in normal and hypercholesterolemic individuals. Furthermore, using the same technique, Carter $e t$ al. (35) measured the absorption of cholesterol in two sisters with homozygous hypercholesterolemia. They were 13 and $16 \mathrm{y}$ of age with cholesterol absorption of 59.1 and $56.4 \%$, respectively, approximately twice the absorption of SLOS children. There are some other absorption data in diseased children in the literature. A boy with $\alpha$-1-antitrypsin deficiency had cholesterol absorption of $34 \%$ at $3 y$ of age and $30 \%$ at $6 y$ of age (36). Illingworth et al. (37) measured the cholesterol absorption of patients with abetalipoproteinemia. One study included one young adult and a 6-y-old boy. Their cholesterol absorption was 30.7 and $36.0 \%$, respectively. Another study involved one 16-y-old girl. Her cholesterol absorption was determined twice to be 34.7 and $30.2 \%$ (38). Abetalipopro- 
teinemia is characterized by the absence of apoprotein-Bcontaining lipoprotein in plasma. This apoprotein is necessary for the synthesis and/or structure of chylomicron. Because chylomicron formation is essential for cholesterol absorption (39), it therefore is likely that the cholesterol absorption of children with abetalipoproteinemia may be lower than the absorption of normal children. Compared with SLOS patients, cholesterol absorption in abetalipoproteinemia patients was slightly higher ( 27.3 versus $30.4 \%$ ).

From the available data described above, the cholesterol absorption by SLOS patients seems low. What causes the lower absorption in these patients? Cholesterol absorption can be affected by many factors $(39,40)$. For example, bile acids are known to affect cholesterol absorption (39-40). Low bile acid synthesis may reduce cholesterol absorption. An early study showed that SLOS children had a low excretion of bile acids (27). In our recent stool balance study, we found that the bile acid synthesis in these patients was somewhat low but did not differ significantly from control subjects (25). In an animal model, Gaoua et al. (41) indicated that 7-DHC competes with cholesterol for absorption. The efficiency of cholesterol esterification in the mucosa cell is another factor that could affect cholesterol absorption (39). In cultured human SLOS fibroblasts, we found defective cholesterol esterification (42). Recent reports indicated that the $\mathrm{ABC}$ transporter genes are important in regulation of cholesterol absorption (43-45). These genes in SLOS patients have not been examined. The actual mechanism that is responsible for the lower absorption of cholesterol in SLOS patients is not known.

Because a usual practice of the cholesterol absorption test is to add isotopic cholesterol to a cholesterol-containing test meal, there were some concerns as to whether this test is representative of the absorption of cholesterol in its natural form, such as egg yolk. In an early study, Cook et al. (28) found that powdered crystalline cholesterol was poorly absorbed compared with egg yolk cholesterol. However, Wilson and Lindsay (46) fed cholesterol in both crystalline and egg yolk form to two subjects to establish an isotopic steady state. They calculated that maximal net cholesterol absorption was similar whether the source of cholesterol was crystalline or egg yolk. In our previous study, we gave test meals that contained either naturally labeled egg yolk cholesterol or a trace dose of labeled crystalline cholesterol dissolved in oil mixed with unlabeled egg yolk to normal subjects as well as type II hypercholesterolemic patients (31). No difference in absorption was found between the test meals that contained two forms of cholesterol. In the present study, we compared the absorption of SLOS patients who were fed the test meal that contained isotopic cholesterol with egg yolk cholesterol or mixing with crystalline cholesterol suspension. The mean absorption of the SLOS test meal that contained egg yolk cholesterol seemed slightly higher than that of crystalline cholesterol $(27.3 \pm 6.7$ versus $20.5 \pm 10.3 \%$ ) but was not statistically significantly different. A study by Wang and Carey (29) indicated that oily vehicles have a significant effect on cholesterol absorption. These factors should be taken into consideration in the design of future studies.
Previously, we had found that the radioactivity of the plasma cholesterol of subjects who had consumed an isotopic test meal reached a maximum in 24 or $48 \mathrm{~h}$ (31). Therefore, we chose these two time points to observe the degree of absorption in SLOS patients. Indirectly, we also evaluated absorption by measuring the unabsorbed isotopic cholesterol in the stool. The correlation between these two different approaches in evaluating absorption was highly significant (Fig. 1). This correlation validated our overall technique in studying the absorption in these children. Wang and Carey (29) compared four standard methods for measuring cholesterol absorption: one direct and three indirect. They found good agreement among these methods. Incidentally, the method that we used for this study is one of the indirect methods that they tested (the fecal dual-isotope ratio method). Furthermore, as our data showed, there was a positive correlation between plasma cholesterol specific radioactivities and intestinal absorption in $\mu \mathrm{Ci} / \mathrm{kg}$ (Fig. 1). If enough data are collected in a given population under controlled conditions to establish the relationship of these two parameters, then perhaps the intestinal absorption of cholesterol can be estimated by plasma radioactivity alone without stool collection. The dual-isotope plasma ratio method was proposed to measure absorption (47). It also does not require stool collection. However, it required two isotopes delivered by mouth and i.v., respectively.

\section{CONCLUSION}

In summary, we measured for the first time the intestinal absorption of cholesterol by SLOS patients. These patients are capable of absorbing cholesterol from the diet. However, their absorption may be less efficient than normal children. Although not statistically significant, crystalline cholesterol tends to be less well absorbed than egg yolk cholesterol by SLOS patients. Besides the form of cholesterol in the diet, cholesterol absorption could be affected by many factors, including fat content of the diet, type of fat in the diet, and frequency of cholesterol administration and compounds such as bile salts, which facilitate cholesterol absorption. Because dietary cholesterol is being used as a principal therapy for these patients, we suggest that a natural source of cholesterol, such as egg yolk, is well absorbed and well tolerated.

Acknowledgments. We thank the staff of the OHSU GCRC. We thank all health care providers who assisted in the care of these patients and for subject referrals to us. We thank Drs. Leesa Linck and Dan Marks for expert assistance with care of research subjects. We thank the children and their families for participation in this study.

\section{REFERENCES}

1. Smith D, Lemli L, Opitz JM 1964 A newly recognized syndrome of multiple congenital anomalies. J Pediatr 64:210-217

2. Curry CJ, Carey JC, Holland JS, Chopra D, Fineman R, Golabi M, Sherman S, Pagon RA, Allanson J, Shulman S, Barr M, et al. 1987 Smith-Lemli-Opitz syndrome type II: multiple congenital anomalies with male pseudohermaphroditism and frequent early lethality. Am J Med Genet 26:45-57

3. Pober B 1990 Smith-Lemli-Opitz syndrome. In: Buyse M (ed) Birth Defects Encyclopedia. Blackwell Scientific, Dover, pp 1570-1572

4. Optiz JM, Pechaszadeh VB, Holt MC, Spano LM 1987 Smith-Lemli-Opitz (RSH) syndrome bibliography. Am J Med Genet 28:745-750 
5. Chasalow FI, Blethen SL, Taysi K 1985 Possible abnormalities of steroid secretion in children with Smith-Lemli-Opitz syndrome and their parents. Steroids 46:827-843

6. Natowicz MR, Evans JE 1994 Abnormal bile acids in the Smith-Lemli-Opitz syndrome. Am J Med Genet 50:364-367

7. Cunniff C, Kratz LE, Moser A, Natowicz MR, Kelley RI 1997 Clinical and biochemical spectrum of patients with RSH/Smith-Lemli-Opitz syndrome and abnormal cholesterol metabolism. Am J Med Genet 68:263-269

8. Ryan AK, Bartlett K, Clayton P, Eaeton S, Mills L, Donnai D, Winter RM, Burn J 1998 Smith-Lemli-Opitz syndrome: a variable clinical and biochemical phenotype. J Med Genet 35:558-565

9. Battaile KP, Battaile B, Merkens LS, Maslen CL, Steiner RD 2001 Carrier frequency of the common mutation IVS8 $-1 \mathrm{G}>\mathrm{C}$ in DHCR7 and estimate of the expected incidence of Smith-Lemli-Opitz syndrome. Mol Genet Metab 72:67-71

10. Tint GS, Irons M, Elias ER, Batta AK, Frieden R, Chen TS, Salen G 1994 Defective cholesterol biosynthesis associated with Smith-Lemli-Opitz syndrome. N Engl J Med 330:107-113

11. Irons ME, Elias ER, Salen G, Tint GS, Batta AK 1993 Defective cholesterol biosynthesis in Smith-Lemli-Opitz syndrome. Lancet 341:1414

12. Tint GS 1993 Cholesterol defect in Smith-Lemli-Opitz syndrome. Am J Med Genet 47:573-574

13. Tint GS, Seller M, Hughes-Benzie R, Batta AK, Shefer S, Genest D, Irons M, Elias E, Salem G 1995 Markedly increased tissue concentrations of 7-dehydrocholesterol combined with low levels of cholesterol are characteristic of the Smith-Lemli-Opitz syndrome. J Lipid Res 36:89-95

14. Honda A, Tint GS, Salen G, Batta AK, Chen TS, Shefer S 1995 Defective conversion of 7-dehydrocholesterol to cholesterol in cultured skin fibroblasts from Smith-LemliOpitz syndrome homozygotes. J Lipid Res 36:1595-1601

15. Shefer S, Salen G, Batta AK, Honda A, Tint GS, Irons M, Elias ER, Chen TC, Holick MF 1995 Markedly inhibited 7-dehydrocholesterol-delta 7-reductase activity in liver microsomes from Smith-Lemli-Opitz homozygotes. J Clin Invest 96:1179-1785

16. Fitzky BU, Witsch-Baumgartner M, Erdel M, Lee JN, Paik YK, Glossman H, Uterman G, Moebius FF 1998 Mutations in the delta 7-sterol reductase gene in patients with the Smith-Lemli-Opitz syndrome. Proc Natl Acad Sci USA 95:81818186

17. Wassif CA, Maslen C, Kachilele-Linjewile S, Lin D, Linck LM, Connor WE, Steiner RD, Porter FD 1998 Mutations in the human sterol delta 7-reductase gene at 11q12-13 cause Smith-Lemli-Opitz syndrome. Am J Hum Genet 63:55-62

18. Waterham HR, Wijburg FA, Hennekam RC, Vreken P, Poll-The BT, Dorland L, Duran M, Jira PE, Smeitink JA, Wevers RA, Wanders RJ 1998 Smith-Lemli-Opitz syndrome is caused by mutations in the 7-dehydrocholesterol reductase gene. Am J Hum Genet 63:329-338

19. Porter JA, von Kessler DP, Ekker SC, Young KE, Lee JJ, Moses K, Beachy PA 1995 The product of hedgehog autoproteolytic cleavage active in local and long-range signaling. Nature 374:363-366

20. Porter JA, Young KE, Beachy PA 1996 Cholesterol modification of hedgehog signaling proteins in animal development. Science 274:255-259

21. Porter JA, Ekker SC, Park WJ, von Kessler DP, Young KE, Chen CH, Ma Y, Woods AS, Cotter RJ, Konnin EV, Beachy PA 1996 Hedgehog patterning activity: role of a lipophilic modification mediated by the carboxy-terminal autoprocessing domain. Cell 86:21-34

22. Cooper MK, Porter JA, Young KE, Beachy PA 1998 Teratogen-mediated inhibition of target tissue response to Shh signaling. Science 280:1603-1607

23. Xu GR, Servatius RJ, Shefer S, Tinit GS, O’Brien WT, Batta AK, Salen G 1998 Relationship between abnormal cholesterol synthesis and retarded learning in rats. Metabolism 47:878-882

24. Gaoua W, Chevy F, Roux C, Wolf C 1999 Oxidized derivatives of 7-dehydrocholesterol induce growth retardation in cultured rat embryos: a model for antenata growth retardation in the Smith-Lemli-Opitz syndrome. J Lipid Res 40:456-463

25. Steiner RD, Linck LM, Flavell DP, Lin DS, Connor WE 2000 Sterol balance in Smith-Lemli-Opitz syndrome. Reduction in whole body cholesterol synthesis and normal bile acid production. J Lipid Res 41:1437-144

26. Linck LM, Lin DS, Flavell D, Connor WE, Steiner RD 2000 Cholesterol supplementation with egg yolk increase plasma cholesterol and decrease plasma 7-dehydrocholesterol in Smith-Lemli-Opitz syndrome. Am J Med Genet 93:360-365
27. Irons M, Elias ER, Tint GS, Salen, G Frieden R, Buie TM, Ampola M 1994 Abnormal cholesterol metabolism in the Smith-Lemli-Opitz syndrome: report of clinical and biochemical findings in four patients and treatment in one patient. Am J Med Genet 50:347-352

28. Cook RP, Edwards DC, Riddle C 1956 Cholesterol metabolism. 7. Cholesterol absorption and excretion in man. Biochem J 62:225-234

29. Wang DQ, Carey MC 2003 Measurement of intestinal cholesterol absorption by plasma and fecal dual-isotope ratio, mass balance, and lymph fistula methods in the mouse: an analysis of direct versus indirect methodologies. J Lipid Res 44:1042-1059

30. Irons M, Elias ER, Abuelo D, Bull MJ, Greene CL, Johnson VP, Keppen L, Schanen C, Tint GS, Salen G 1997 Treatment of SLO syndrome: results of a multi center trial. Am J Med Genet 68:311-314

31. Connor WE, Lin DS 1974 The intestinal absorption of dietary cholesterol by hypercholesterolemic (type II) and normocholesterolemic humans. J Clin Invest 53:1062-1070

32. Rapp JH, Connor WE, Lin DS, Inahara T, Porter JM 1983 Lipids of human atherosclerotic plaques and xanthomas: clues to the mechanism of plaque progression. J Lipid Res 24:1329-1335

33. Lin DS, Connor WE 1980 The long term effects of dietary cholesterol upon the plasma lipids, lipoproteins, cholesterol absorption, and the sterol balance in man: the demonstration of feedback inhibition of cholesterol biosynthesis and increased bile acid excretion. J Lipid Res 21:1042-1052

34. Miettinen TA, Ahrens EH Jr, Grundy SM 1965 Quantitative isolation and gas-liquid chromatography analysis of total dietary and fecal neutral steroids. J Lipid Res 79:411-424

35. Carter GA, Connor WE, Bhattacharyya AK, Lin DS 1979 The cholesterol turnover, synthesis, and absorption in two sisters with familial hypercholesterolemia (type IIa). J Lipid Res 20:66-77

36. Diliberti JH, McMurry MP, Connor WE, Alaupovic P 1984 Hypercholesterolemia associated with alpha-1-antitrypsin deficiency and hepatitis: lipoprotein and apoprotein determinations, sterol balance and treatment. Am J Med Sci 288:81-85

37. Illingworth DR, Connor WE, Lin DS, Diliberti J 1980 Lipid metabolism in abetalipoproteinemia: a study of cholesterol absorption and sterol balance in two patients. Gastroenterology 78:68-75

38. Illingworth DR, Connor WE, Buist NR, Jhaveri BM, Lin DS, McMurry MP 1979 Sterol balance in abetalipoproteinemia: studies in a patient with homozygous familial hypobetalipoproteinemia. Metabolism 28:1152-1160

39. Treadwell CR, Vahouny GV 1968 Cholesterol absorption. Handbook of Physiology. Sec. 6. Alimentary Canal Vol. III. American Physiological Society, Washington, DC, pp. $1407-1438$

40. Grundy SM 1983 Absorption and metabolism of dietary cholesterol. Am Rev Nutr 3:71-96

41. Gaoua W, Wolf C, Chevy F, Ilien F, Roux C 2000 Cholesterol deficit but not accumulation of aberrant sterols is the major cause of the teratogenic activity in the Smith-Lemli-Opitz syndrome animal model. J Lipid Res 41:637-646

42. Wassif CA, Vied D, Tsokos M, Connor WE, Steiner RD, Porter FD 2002 Cholesterol storage defect in RSH/Smith-Lemli-Opitz syndrome fibroblasts. Mol Genet Metab 75:325-334

43. McNiesh J, Alello RJ, Guyot D, Turl T, Gabel C, Aldinger C, Hoppe KL, Roach ML, Royer LJ, de Wet J, Broccardo C, Chimini G, Francone OL 2000 High density lipoprotein deficiency and foam cell accumulation in mice with targeted disruption of ATP-binding cassette transporter-1. Proc Natl Acad Sci USA 97:4245

44. Repa JJ, Turley SD, Lobaccaro JA, Medina J, Li L, Lustig K, Shan B, Heyman RA, Dietschy JM, Mangelsdorf DJ 2000 Regulation of absorption and ABC1-mediated efflux of cholesterol by RXR heterodimers. Science 289:1527

45. Allayee H, Laffitte BA, Lusis AJ 2000 Biochemistry. An absorbing study of cholesterol. Science 290:1709-171

46. Wilson JD, Lindsey CH Jr 1965 Studies on the influence of dietary cholesterol metabolism in isotopic steady state in man. J Clin Invest 44:1805-1814

47. Turley SD, Herndon MW, Dietschy JM 1994 Reevaluation and application of dual-isotope plasma ratio method for the measurement of intestinal cholesterol absorption in the hamster. J Lipid Res 35:328-339 